\title{
Final Year Medical Students' Perspective on the Use of Peer Assessments in the Training of Future Doctors to Obtain and Provide Quality Feedback [Letter]
}

Ibrahim Hussain (D)

Mubashar Ameen

Hamdip Singh

University of Nottingham, Faculty of Medicine and Health Sciences, Medical School, Queen's Medical Center, Nottingham NG7 2UH, England
Correspondence: Ibrahim Hussain University of Nottingham, Faculty of Medicine and Health Sciences, Medical School, Queen's Medical Center, Nottingham NG7 2UH, England Email ibrahim_250@hotmail.co.uk
This article was published in the following Dove Press journal:

Advances in Medical Education and Practice

\section{Dear editor}

The paper on the use of peer assessments in the training of medical students to obtain and provide quality feedback, by Lerchenfeldt and Taylor, ${ }^{1}$ was read with great interest.

The authors provided an intriguing insight into the current use of peer assessments and how they could be better incorporated into the curriculum. We, as final year medical students, believe that there are other factors which should also be considered.

Students providing honest feedback is key for the success of peer assessments. In order to achieve this, the study suggests creating a safe and trustworthy environment for students. However, agreement within the group can lead to collusion, producing falsely positive feedback. ${ }^{2}$ Many agendas, such as anxieties about peer relationships and obtaining higher marks, can become cause for collusion. If feedback is fixed from the outset, irrespective of an individual's performance, it nullifies its use in aiding students in becoming better doctors. One method of tackling this issue could be to anonymize assessment forms, enabling students to be truthful when providing feedback.

The authors state medical students and their faculties require training to utilize peer assessments effectively; often failure of these assessments is due to the lack of preparedness. The issue with conducting effective peer assessments lies with the current medical curricula being time constrained. ${ }^{3}$ Although adjustments can be made, this could result in reduced teaching and clinical exposure. This presents a challenge, considering medical students feel the need to gain more clinical experience in order to better prepare themselves as future doctors. ${ }^{4}$ Thus, we believe it is essential to consider the students' perspectives when proposing changes to medical curricula, which could be achieved by carrying out formal needs assessments.

We agree with the authors that peer assessments are underutilized in medical education. From our experience, the first and only exposure to peer feedback was during the primary care attachment in the fourth year. A lack of standardized quality criteria when providing feedback was evident; this led to some students finding 
feedback more beneficial than others. As the study mentions, in order to provide reliable feedback, it is important to consider the amount of relevant performances observed. However, our medical school encourages working with different peers to build new relationships. Consequently, we do not observe an adequate number of performances and therefore are unable to provide reliable feedback.

To conclude, whilst we agree with the authors on the utilization of peer assessments in medical education, we believe implementing this can pose certain challenges. For example, student bias to falsify assessments, the need for current curricula to be reviewed and understanding students' perspectives when tailoring the curriculum. The points raised in this letter, along with our own experience, strongly support the need for further investigation. We look forward to future studies exploring these factors.

\section{Disclosure}

The authors report no conflicts of interest in this communication.

\section{References}

1. Lerchenfeldt S, Taylor TAH. Best practices in peer assessment: training tomorrow's physicians to obtain and provide quality feedback. Adv Med Educ Pract. 2020;11:571-578. doi:10.2147/AMEP.S250761

2. Biesma R, Kennedy M, Pawlikowska T, et al. Peer assessment to improve medical student's contributions to team-based projects: randomised controlled trial and qualitative follow-up. BMC Med Educ. 2019;19(1):371. doi:10.1186/s12909-019-1783-8

3. Li L, Gao F Effect of peer assessment on project performance of students at different learning levels. Visual Communication and Technology Education Faculty Publications; 2015:33. Available from: https://scholar works.bgsu.edu/vcte_pub/33. Accessed September 18, 2020.

4. General Medical Council. Clinical placements for medical students; 2011. Available from: https://www.gmc-uk.org/-/media/documents/ Clinical_placements_for_medical_students 56437824.pdf. Accessed September 18, 2020.

Dove Medical Press encourages responsible, free and frank academic debate. The content of the Advances in Medical Education and Practice 'letters to the editor' section does not necessarily represent the views of Dove Medical Press, its officers, agents, employees, related entities or the Advances in Medical Education and Practice editors. While all reasonable steps have been taken to confirm the content of each letter, Dove Medical Press accepts no liability in respect of the content of any letter, nor is it responsible for the content and accuracy of any letter to the editor.

\section{Publish your work in this journal}

Advances in Medical Education and Practice is an international, peerreviewed, open access journal that aims to present and publish research on Medical Education covering medical, dental, nursing and allied health care professional education. The journal covers undergraduate education, postgraduate training and continuing medical education including emerging trends and innovative models linking education, research, and health care services. The manuscript management system is completely online and includes a very quick and fair peer-review system. Visit http://www.dovepress.com/testimonials.php to read real quotes from published authors. 